\title{
Tadpole of Pithecopus rusticus (Bruschi, Lucas, Garcia \& Recco-Pimentel, 2014) (Anura, Phyllomedusidae): description of external morphology and natural history notes of a microendemic species
}

\author{
Veluma Ialú Molinari De Bastiani ${ }^{1 *}{ }^{\circledR}$, Joana Priscilla Boschetti2 ${ }^{2}$ Tiago Gomes dos Santos $^{3}$ \& \\ Elaine Maria Lucas ${ }^{4}$ \\ ${ }^{1}$ Universidade Comunitária da Região de Chapecó, Chapecó, SC, Brasil \\ ${ }^{2}$ Universidade Comunitária da Região de Chapecó, Programa de Pós Graduação em Ciências Ambientais, \\ Chapecó, SC, Brasil \\ ${ }^{3}$ Universidade Federal do Pampa, Campus de São Gabriel, São Gabriel, RS, Brasil \\ ${ }^{4}$ Universidade Federal de Santa Maria, Departamento de Zootecnia e Ciências Biológicas, Campus de \\ Palmeira das Missões, RS, Brasil \\ *Corresponding author: Veluma Ialú Molinari De Bastiani, e-mail: veluma@unochapeco.edu.br
}

BASTIANI, V. I. M., BOSCHETTI, J. P., SANTOS, T. G., LUCAS, E. M. Tadpole of Pithecopus rusticus (Bruschi, Lucas, Garcia \& Recco-Pimentel, 2014) (Anura, Phyllomedusidae): description of external morphology and natural history notes of a microendemic species. Biota Neotropica. 19(1): e20180570. http://dx.doi.org/10.1590/1676-0611-BN-2018-0570

\begin{abstract}
Pithecopus rusticus is a newly described species, of which information on its natural history, vocalization and tadpole morphology are still lacking. Here, we describe the larval external morphology of $P$. rusticus from the type locality, in the municipality of Água Doce, state of Santa Catarina, southern Brazil, comparing it with that of other species of the genus Pithecopus and providing information on its natural history. Eggs from two spawns were collected and kept in the laboratory until hatching. The tadpoles of $P$. rusticus belong to the suspension-rasper guild. At Gosner stage 37, the tadpoles showed: body shape oval in dorsal view and triangular in lateral view; a tooth row formula of 2(2)/3(1); the third lower row six times shorter than others; marginal papillae uniserial, interrupted by a wide dorsal gap and with rounded tips; and a single row of alternate marginal papillae on lower lip. External morphological features were compared with those of other tadpoles of Pithecopus. Observations on the natural history of P. rusticus are also reported.
\end{abstract}

Keywords: Taxonomy, Grasslands, Atlantic Forest.

\section{Girino de Pithecopus rusticus (Bruschi, Lucas, Garcia \& Recco-Pimentel, 2014) (Anura, Phyllomedusidae): descrição da morfologia externa e notas sobre a história natural de uma espécie microendêmica}

\footnotetext{
Resumo: Pithecopus rusticus é uma espécie recém-descrita, cujas informações sobre a história natural, vocalização e morfologia larval permanecem ausentes. Aqui, descrevemos a morfologia externa larval de P. rusticus da localidade-tipo, município de Água Doce, estado de Santa Catarina, sul do Brasil, comparando-a com outras espécies do gênero Pithecopus e fornecendo informações sobre sua história natural. Ovos de duas desovas foram coletados e mantidos no laboratório até a eclosão. Os girinos de $P$. rusticus pertencem à guilda de raspador em suspensão. No estágio 37 de Gosner, os girinos apresentam: corpo oval em vista dorsal e triangular em vista lateral; fórmula de fileira de dente de 2(2)/3(1); terceira fileira inferior seis vezes mais curta que as demais; papilas marginais unisseriadas, interrompidas em amplo espaço dorsal e com pontas arredondadas; uma única fileira de papilas marginais alternadas no lábio inferior. Características morfológicas externas foram comparadas com as de outros girinos de Pithecopus. Observações sobre a história natural de P. rusticus também são relatadas.
}

Palavras-chave: Taxonomia, Campos, Mata Atlântica. 


\section{Introduction}

The neotropical amphibian genus Pithecopus Cope, 1866 was recently resurrected (Duellman et al. 2016) to include the species that were formerly assigned to the Phyllomedusa hypochondrialis group (sensu Faivovich et al. 2005, 2010). Pithecopus is distributed from tropical South America east of the Andes and southern Venezuela to northern Argentina and southern Brazil (Frost 2018). The genus Pithecopus is currently diagnosed by the following combination of characteristics (Duellman et al. 2016): medium-size (snout-vent length $\pm 45 \mathrm{~mm}$ ); toe I much longer than and opposable to toe II; vomerine teeth absent; and tadpoles with a somewhat small anteroventral oral disc. In general, the species are associated with a wide variety of habitats, such as temporary and permanent ponds and streams in forests or open formations (Brandão 2002, Brandão et al. 2009, Pezzuti et al. 2009). The species currently recognized in the genus Pithecopus are $P$. araguaius Haga, Andrade, Bruschi, Recco-Pimentel \& Giaretta, 2017, P. ayeaye Lutz, 1966, P. azureus (Cope, 1862), P. centralis (Bokermann, 1965), P. hypochondrialis (Daudin, 1800), P. megacephalus (Miranda-Ribeiro, 1926), P. nordestinus (Caramaschi, 2006), P. oreades (Brandão, 2002), P. palliatus (Peters, 1873), P. rohdei (Mertens, 1926) and P. rusticus (Bruschi, Lucas, Garcia \& Recco-Pimentel, 2014). On the basis of molecular, chromosomal, and morphological approaches, Bruschi et al. (2014) described P. rusticus as a new species, and it was later included in the genus Pithecopus (Segalla et al. 2016), but not considered in the review by Duellman et al. (2016).

Currently, nine species of this genus have a formal description of tadpoles: P. ayeaye (Lutz 1966, Cruz 1982, Pezzuti et al. 2009 - as P. itacolomi), P. azureus (Cei 1980, Schulze et al. 2015), P. centralis (Brandão et al. 2009), P. hypochondrialis (Pyburn \& Glidewell1971, Martínez 1990), P. megacephalus (Cruz 1982 as P. centralis according to Brandão 2002 and Eterovick \& Sazima 2004), P. nordestinus (Cruz 1982 - as $P$. hypochondrialis, according to Caramaschi 2006), $P$. oreades (Brandão 2002), P. palliatus (Duellman 1978), and $P$. rohdei (Cruz 1982). Herein, we describe the external morphology of $P$. rusticus tadpoles from natural grasslands (sensu Klein 1978) in the highlands of the Atlantic Forest biome in southern Brazil, comparing them with those of other species of the genus Pithecopus and providing information on natural history.

\section{Material and Methods}

We collected two leaf nests with spawns of P. rusticus from a pond of the type locality, in the municipality of Água Doce, state of Santa Catarina, southern Brazil (26³5'59.9'S, 51³4'39.4'W; 1,330 $\mathrm{m}$ a.s.1.), on December 6, 2016. We kept the tadpoles in an aquarium with water under the spawns until the tadpoles hatched. All tadpoles hatched in two days after collection of spawns. We kept tadpoles in the aquarium with pond vegetation. Half of the aquarium water was changed every seven days. The tadpoles were fed with pond vegetation, and every seven days were provided fish and turtle feed. Some tadpoles were reared until the end of metamorphosis to confirm species identity. Tadpoles were anesthetized with $0.1 \%$ lidocaine and then fixed in $10 \%$ formalin. Voucher specimens were submitted to the Scientific Collection of Amphibians of the Universidade Comunitária da Região de Chapecó, municipality of Chapecó, state of Santa Catarina, Brazil: tadpoles (lots CAUC 001, 003-007), froglet (CAUC 2396) and metamorphosed frog
(CAUC 2243-2244). The pond where we collected the tadpoles has an area of approximately $2750 \mathrm{~m}^{2}$ and depth ranging from $10 \mathrm{~cm}$ (near the margin) to $3 \mathrm{~m}$ (in the center of the pond) and is located next to an unpaved road (SC-452 Highway) of a private farmland. The central and marginal portions of the pond were covered with herbaceous vegetation. The marginal vegetation is often removed to facilitate cattle access to water. The ponds were surrounded by crops, which were less than $2 \mathrm{~m}$ from the margins.

External morphology descriptions were based on 15 tadpoles at stage 37 (Gosner 1960) and 21 morphological measurements were taken according to Lavilla \& Scrocchi (1986): maximum body width (BW), maximum body height $(\mathrm{BH})$, maximum eye diameter (ED), maximum nostril diameter (ND), nostril-snout distance (NSD), eye-snout distance (ESD) and oral disc diameter (ODD); McDiarmid \& Altig (1999): maximum tail height (MTH); Grosjean (2005): maximum ventral fin height (VFH), maximum dorsal fin height (DFH); Altig (2007): total length (TL), body length (BL), tail length (TAL), tail musculature width (TMW), tail musculature height (TMH), interorbital distance (IOD), and internarial distance (IND). Additional measurements were recorded for jaw sheaths, following the dimensions proposed by McDiarmid \& Altig (1999): lower jaw sheath length (LJSL), lower jaw sheath height (LJSH), upper jaw sheath length (UJSL), and upper jaw sheath height (UJSH). Tadpole measurements were made using a stereomicroscope with an ocular micrometer $(0.01 \mathrm{~mm}$ precision $)$, except for total length and body length, which were measured with a digital caliper $(0.01$ $\mathrm{mm}$ precision) (Table 1). Comparisons with tadpoles of other species of Pithecopus, as well as the description of possible intrapopulation morphological variation of $P$. rusticus were provided for an additional 25 individuals (stages 27, 33, 35-36) (Gosner 1960) using the same set of measurements described above (Table 2). All tadpoles were inspected for the presence of the lateral line system (Lannoo 1999).

\section{Results}

Tadpole description. Measurements for all available development stages are given in Table 1 . The tadpoles of $P$. rusticus have an elongated body (BH/BW: 1.02); body length approximately one-third of the total length (BL/TL: 0.36); body oval in dorsal view and triangular in lateral view (Figure 1); snout slightly truncated in dorsal and lateral views; nostrils oval and anterolateral, closer to tip of snout than to eyes; IND larger than the NSD (IND/NSD: 3.06); eyes lateral; IOD greater than ESD (IOD/ESD: 1.94); spiracle ventral, sinistral, short and wide, posteriorly directed, opening on middle third of body; inner wall absent; vent tube dextral, short and narrow, posteriorly directed, fused to ventral fin, with free opening; tail longer and taller than the body (TAL/TL: 0.63; MTH/BH: 1.01) curved toward ventral surface, with flagellum; tail musculature higher than wide (TMH/TMW: 1.31), well developed throughout the tail length; dorsal fin lower than ventral fin (DFH/VFH: 0.47); dorsal fin beginning on the posterior third of the body, originating anteriorly to the body-tail junction, at a median slope and extending to the tail tip; ventral fin origin anterior to vent tube extending to tail tip; the lateral line system is not visible; oral disc anteroventral, anteriorly directed, not emarginated; marginal papillae uniserial with rounded tips, wide dorsal gap present (Figure 2); single row of alternate marginal papillae on lower lip and lateral portion; submarginal papillae laterally aggregate, not forming rows; jaw sheaths darkly pigmented, edge finely 
Table 1. Morphological measurements (in mm) of 40 tadpoles of Pithecopus rusticus from the municipality of Água Doce, state of Santa Catarina, southern Brazil. Data presented as mean + standard deviation (range). The sample size is in parentheses, below the larval stage. TL - total length, BL - body length, BW - maximum body width, $\mathrm{BH}$ - maximum body height, TAL - tail length, MTH - maximum tail height, TMW - tail musculature width, TMH - tail musculature height, DFH - maximum dorsal fin height, VFH - maximum ventral fin height, IOD - interorbital distance, IND - internarial distance, ESD - eye-snout distance, NSD nostril-snout distance, ED - maximum eye diameter, ND - maximum nostril diameter, ODD - oral disc diameter, LJSL - lower jaw sheath length, LJSH - lower jaw sheath height, UJSL - upper jaw sheath length, UJSH - upper jaw sheath height.

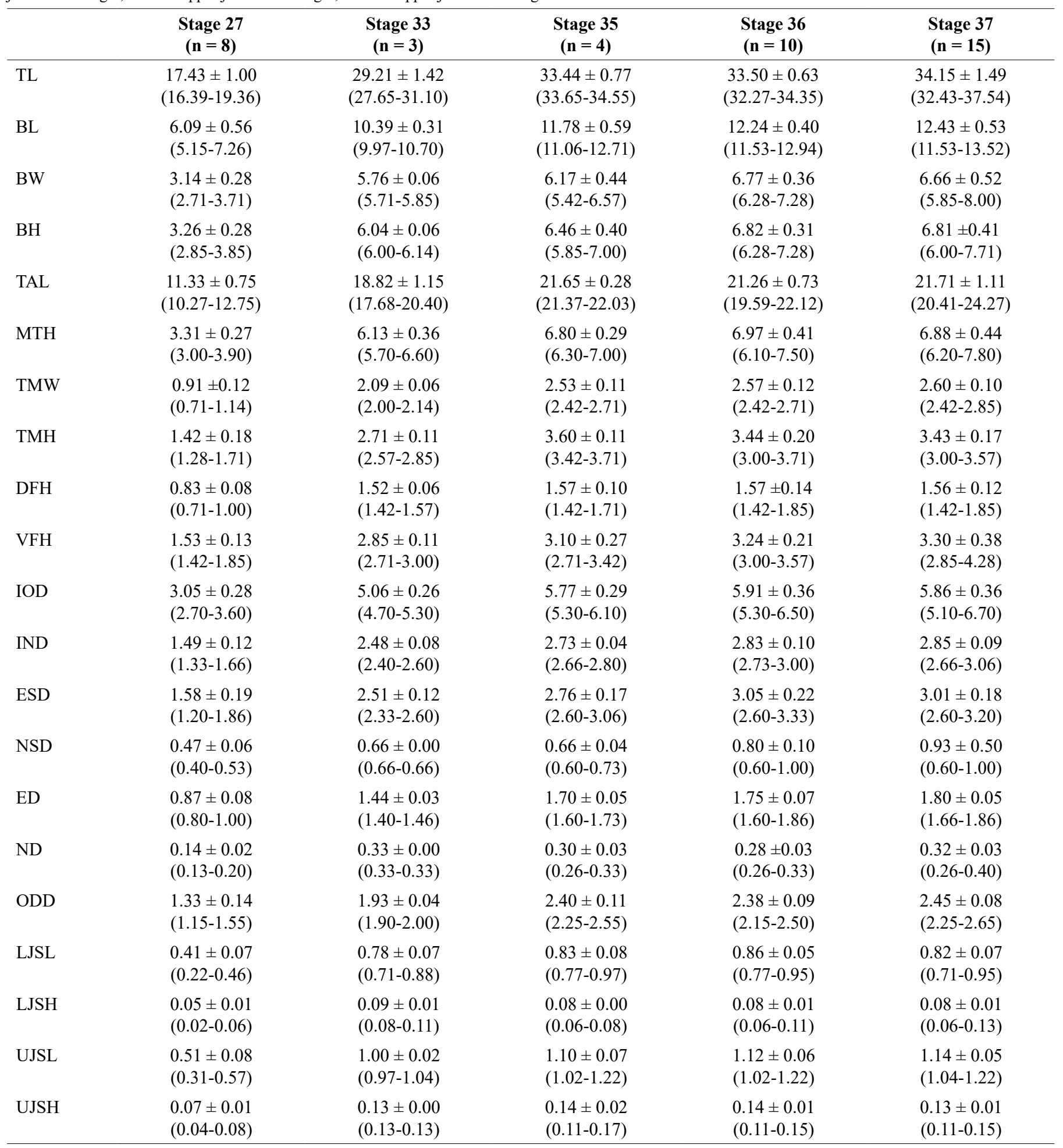


Bastiani, V.I.M. et al.

Table 2. Comparison of external morphological characteristics between tadpoles of species from the genus Pithecopus.

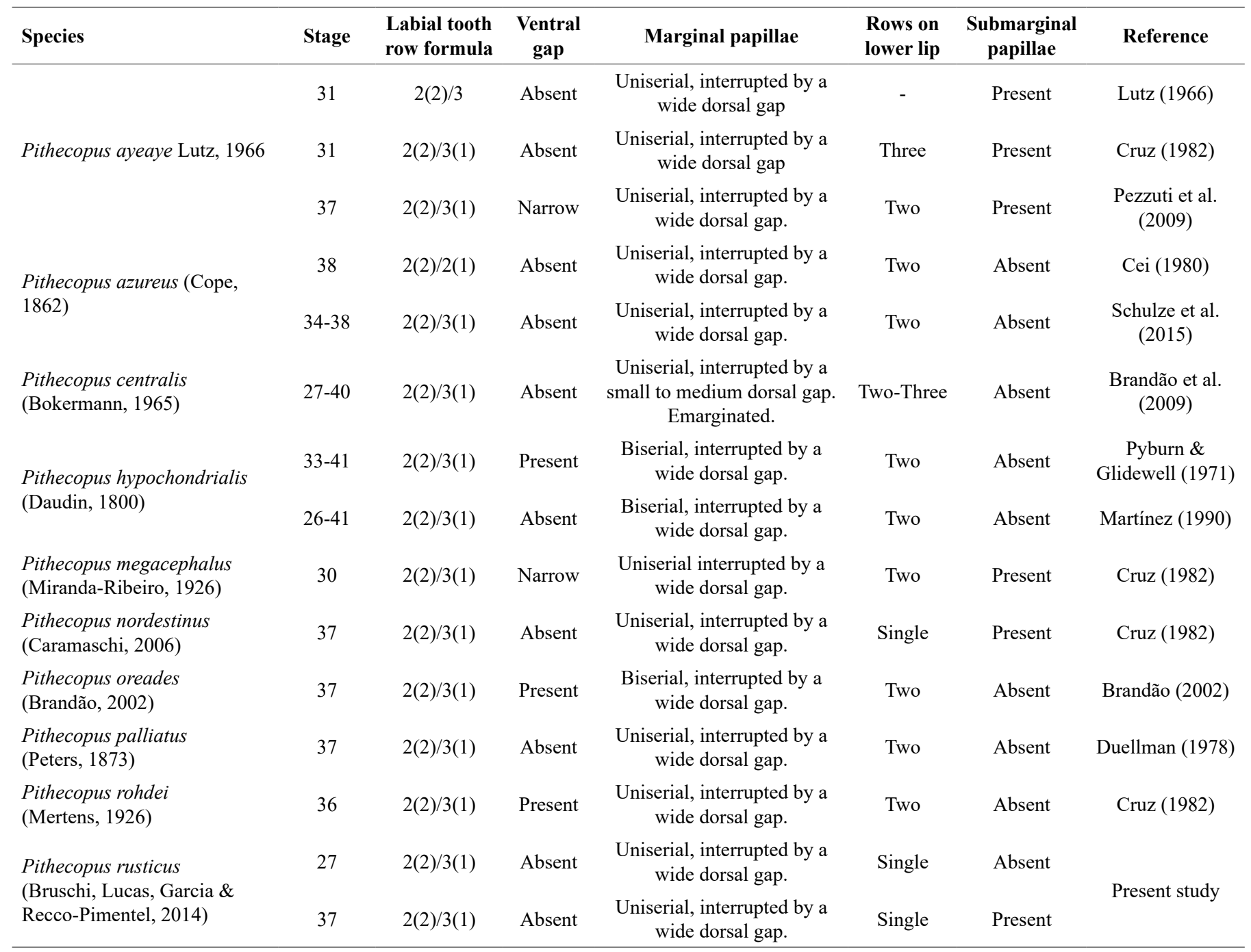

serrated; upper jaw sheath M-shaped; lower sheath V-shaped; upper jaw sheath wider than high (UJSL/UJSH: 8.76); lower jaw longer than high (LJSL/LJSH: 10.25); tooth row formula 2(2)/3(1); A1 and A2 with same length; P1 slightly longer than P2; P3 smaller than P1 and P2 (Figure 2). Body, tail and fins yellow; dorsal and lateral surface of the body, tail musculature and fin with scattered brown dots, more evident along tail musculature and ventral fin; tail tip and flagellum transparent; irregular longitudinal stripes along the middle and ventral margin of tail musculature; lateral dark brown strip, from oral disc to eye, sometimes continuing beyond eye (Figure 3A); iris spotted with golden coloration; bright metallic peritoneum, ranging from gold, orange and yellowish-green to violet. In fixed tadpoles yellow turns cream; peritoneum turns faded violet; iris turns black (Figure 1). The color pattern of the metamorphosing specimens is the same as that of the froglet and adult (Figure 3B).

Morphological variation. The length of the labial tooth row of three tadpoles at Gosner stage 37 (20\% of the lot) varied with A1 > A2. A single individual at stage 37 (6.66\% of the lot) exhibited P1 and P2 interrupted and another exhibited only P1 interrupted. Also, at stage 37 , submarginal papillae of five tadpoles $(33.33 \%$ of the lot $)$ were absent, and in another five tadpoles (33.33\% of the lot) the upper jaw sheaths were arc-shaped. The tadpoles of $P$. rusticus showed ontogenetic variation (Table 2). The vent tube of six tadpoles at stage 27 (75\% of the lot) was dextral, directed downward, while in two tadpoles $(25 \%$ of the lot), the vent tube was like that at stage 37, dextral and directed posteriorly. At stage 27, the dorsal fin started in the middle third of the body. The lateral line system was visible at stage 27, exhibiting two lines on the side of the body, one line over the body bordering part of the tail muscle, and another surrounding the eyes and nostrils. The labial tooth row formula of all tadpoles at stage $27(100 \%$ of the lot) was $2(2) / 3(1)$, with $\mathrm{A} 1$ longer than $\mathrm{A} 2, \mathrm{P} 1$ longer than $\mathrm{P} 2$ and $\mathrm{P} 3$ smaller than $\mathrm{P} 1$ and $\mathrm{P} 2$, but $\mathrm{P} 3$ was tiny, where it could be confused with it being absent. However, in four tadpoles ( $50 \%$ of the lot), P3 was absent. Submarginal papillae of all tadpoles at stage $27(100 \%$ of the lot $)$ were absent and upper jaw sheath was arc-shaped (Table 2).

Natural history and conservation notes. Adults of $P$. rusticus deposit eggs on individual leaves of Senecio bonariensis Hook \& Arn. (Asteraceae), along the margins of the pond, approximately $23.5 \pm 6.41$ $\mathrm{cm}(15-36 \mathrm{~cm} ; \mathrm{n}=16)$ above the water surface. We did not observe the tadpoles in the natural environment. In the laboratory, P. rusticus 


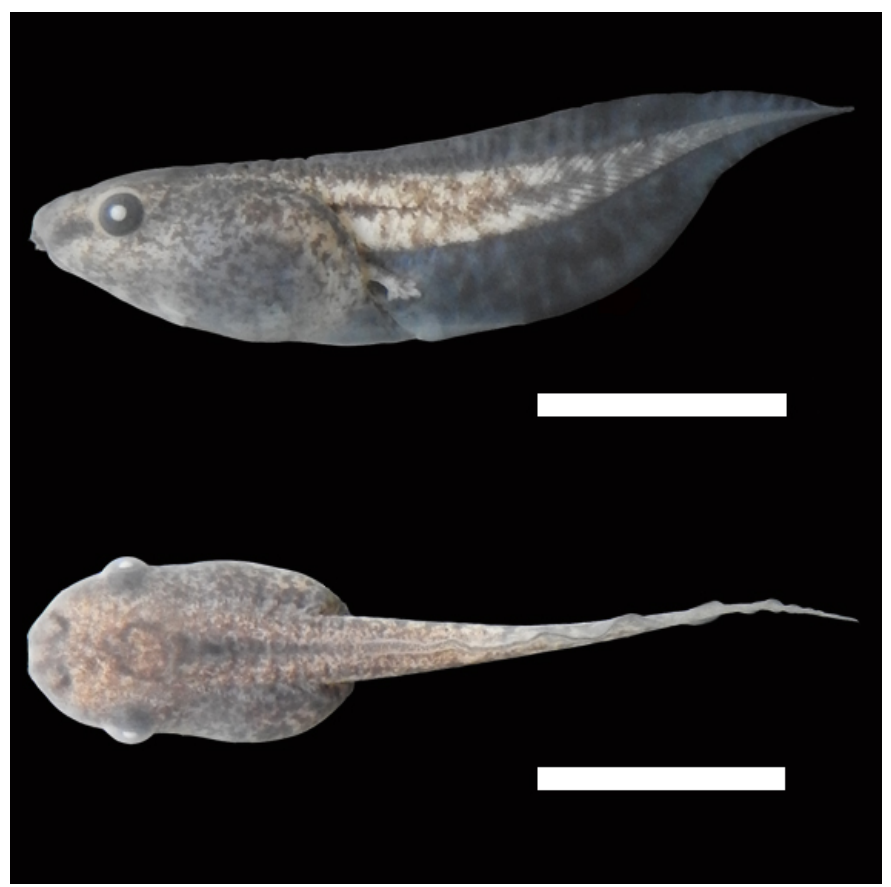

Figure 1. Tadpole of Pithecopus rusticus at Gosner stage 36 (Lot CAUC 003) in lateral view (top) and dorsal view (down). Scale: $10 \mathrm{~mm}$.

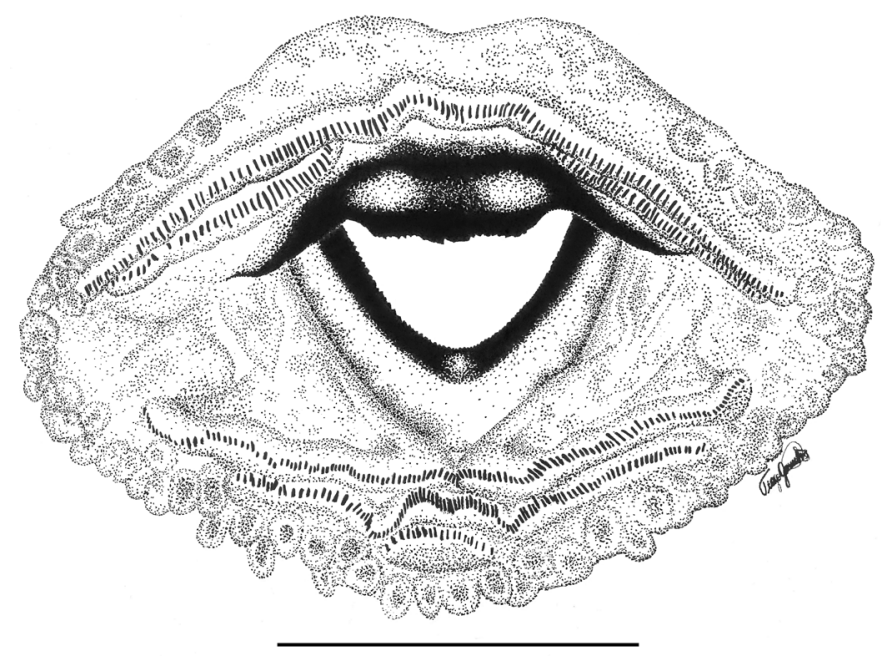

Figure 2. Oral disc from of the tadpole of Pithecopus rusticus at Gosner stage 37 (Lot CAUC 004). Scale: $1 \mathrm{~mm}$.

tadpoles did not aggregate, and were observed at mid-water, floating with quick and short movements of their tail tips, with their bodies inclined upwards at an angle of approximately $90^{\circ}$ with the water surface; when disturbed, they promptly fled to deeper regions. The tadpoles of P. rusticus belong to the suspension-rasper guild (McDiarmid \& Altig 1999). Tadpoles of Dendropsophus minutus (Peters, 1872), D. sanborni (Schmidt, 1944) and Physalaemus cuvieri Fitzinger, 1826, and potential predators such as Phrynops williamsi Rhodin \& Mittermaier, 1983, Erythrolamprus miliaris (Linnaeus, 1758) and aquatic insects (Belostomatidae and Odonata), were observed in the same pond inhabited by P. rusticus.
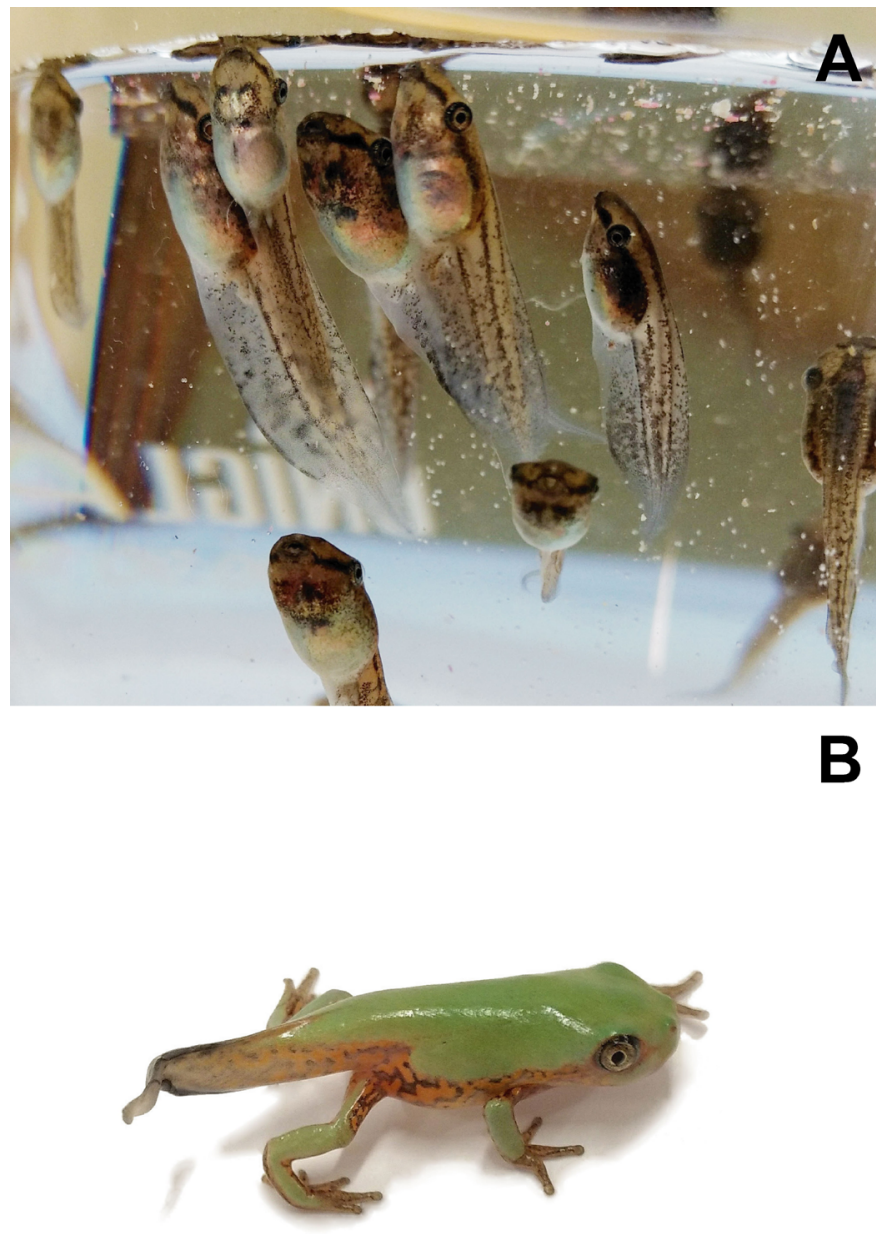

Figure 3. Tadpoles of Pithecopus rusticus at Gosner stage 36 in life (A, Lot CAUC 004) and froglet at Gosner stage 44 (B, CAUC 2396, SVL $16.14 \mathrm{~mm}$ ).

\section{Discussion}

Tadpoles of Pithecopus rusticus are similar to those of other species of the genus, regarding most of the external morphology characters, such as the oval shape of the body in dorsal view (except $P$. oreades, in which the body is trapezoidal), anteroventral oral disc surrounded by a row of marginal papillae interrupted by a wide dorsal gap, vent tube dextral, short and attached to the ventral fin, ventral fin higher than dorsal fin, and labial tooth row formula 2(2)/3(1), with P3 smaller than P1 and P2 (Pyburn \& Glidewell 1971, Duellman 1978, Cruz 1982, Brandão 2002, Brandão et al. 2009, Pezzuti et al. 2009, Schulze et al. 2015). Tadpoles of $P$. rusticus can be diagnosed from those of the remaining species of the genus by the following combination of oral disc characteristics: uniserial marginal papillae being alternate on lower lip and lateral portion of oral disc and interrupted by a wide dorsal gap, oral disc not emarginate, submarginal papillae laterally aggregate in the oral disc, not forming rows, upper jaw sheath M-shaped and lower jaw sheath V-shaped. Pithecopus ayeaye has two rows of marginal papillae on the 
lower lip and lateral portion, with a narrow ventral gap (Lutz 1966, Cruz 1982, Pezzuti et al. 2009); P. azureus has uniserial to irregularly aligned biserial rows on lower lip and no submarginal papillae (Cei 1980, Schulze et al. 2015); P. centralis has an emarginate oral disc, a single row of marginal papillae on each side of the rostral gap, extending into two and three rows of papillae, with numerous papillae on the lateral margins and lower lip and no submarginal papillae (Brandão et al. 2009); $P$. hypochondrialis has two rows of marginal papillae and no submarginal papillae (Pyburn \& Glidewell 1971, Martínez 1990); P. megacephalus has two rows of marginal papillae on the lower lip and lateral portion, with a narrow ventral gap (Cruz 1982); P. nordestinus differs only by non-alternate marginal papillae (Cruz 1982); P. oreades has two rows of papillae on posterior margin, one row of small papillae on the anterior margin, small and scattered lateral papillae in the transverse mouth midline and no submarginal papillae (Brandão 2002); P. palliatus has two rows of marginal papillae ventrally and no submarginal papillae (Duellman 1978); P. rohdei has two rows of marginal papillae on the lower lip and lateral portion and no submarginal papillae (Cruz 1982); $P$. ayeaye and $P$. centralis are the only species in the genus that have the upper jaw sheath M-shaped, while the others have it arc-shaped; $P$. azureus is the only species with the lower jaw sheath U-shaped, while the others have it V-shaped. Giaretta et al. (2007) pointed out that the narrow ventral gap characteristic could vary ontogenetically in $P$. ayeaye tadpoles. Accordingly, morphological variation in larvae of $P$. rusticus (size of third lower row and presence/absence of submarginal papillae) was related to total length of the body.

The species phylogenetically closest to $P$. rusticus are $P$. ayeaye, $P$. centralis and $P$. oreades (Bruschi et al. 2014). In addition to differences in oral disc (see above), P. rusticus tadpole differs from these species by nostrils positioned anterolaterally (dorsolaterally positioned in $P$. ayeaye, $P$. centralis and $P$. oreades), eyes positioned laterally in $P$. rusticus and $P$. ayeaye (dorsolaterally positioned in $P$. centralis and $P$. oreades), and spiracle ventral with free opening, located on the left side in $P$. rusticus and $P$. ayeaye (spiracle positioned over the horizontal midline in $P$. centralis and $P$. oreades). Yet, the M-shaped upper jaw sheath is similar to those of Pithecopus species, except $P$. oreades, in which it is arc-shaped (Lutz 1966, Cruz 1982, Brandão 2002, Brandão et al. 2009, Pezzuti et al. 2009). The tadpole of $P$. rusticus is morphologically closer to that of $P$. ayeaye than $P$. centralis and $P$. oreades, and the same pattern was shown by Bruschi et al. (2014) for adults.

Pithecopus rusticus lays eggs attached to vegetation above the water surface of ponds. Each leaf nest is composed of just one leaf, and eggs hatch into tadpoles, which drop into the lentic water (reproductive mode 24 of Haddad \& Prado 2005). This reproductive mode is also reported to $P$. azureus, $P$. hypochondrialis, $P$. megacephalus, $P$. nordestinus, $P$. palliatus and P. rohdei (Pyburn \& Glidewell 1971, Duellman 1978, Cruz 1982, Martínez 1990, Schulze et al. 2015). However, it differs in $P$. ayeaye, $P$. centralis and $P$. oreades (Lutz 1966, Cruz 1982, Brandão 2002, Brandão et al. 2009, Pezzuti et al. 2009), which deposit eggs above streams in nests composed of just one folded leaf and whose larvae complete their development in creek pools and backwaters (reproductive mode 25, Haddad \& Prado 2005). Tadpoles of all Pithecopus species show a characteristic position, nearly vertical, with the mouth toward the surface, with small movements of their tail tips (Lutz 1966, Pyburn \& Glidewell1971, Duellman 1978, Cruz 1982, Martínez 1990, Brandão 2002, Brandão et al. 2009, Pezzuti et al. 2009, Schulze et al. 2015).
In summary, tadpoles of $P$. rusticus are similar to those of other species of the genus Pithecopus, especially $P$. ayeaye. Interestingly, $P$. rusticus has a distribution that is isolated from all other species of the genus, where it is known to occur at present only at its type locality with a restricted distribution in the high plateaus of western state of Santa Catarina, in the region known as Campos de Palmas (i.e. natural grassland landscape), in southern Brazil. The inclusion of P. rusticus at the species list of amphibians in grasslands of Paraná state (Crivellari et al. 2014) was based on the record of this species at the type locality (i.e. Água Doce, state of Santa Catarina, Brazil; Crivellari in personal communication), which is placed in the surrounds of Palmas Wildlife Refuge. Sampling efforts related to anuran surveys carried out by unrelated herpetologist teams at the region during approximately the last ten years failed to detect this species in additional localities (EML unpublished data and personal communication from L. Pedroso and L. Crivellari). In addition, this region has suffered intense anthropic changes due to the transformation of large grassland areas into monoculture of Pinus sp. and accelerated expansion of agriculture, especially soybeans and potatoes (Overbeck et al. 2009, Pillar \& Vélez 2010). Unfortunately, the breeding habitat of $P$. rusticus is now under high anthropogenic pressure, since exotic fishes were introduced to the pond and because a dam construction project has been stated in the pond surroundings (involving removal of soil and vegetation in the whole area). Thus, according to current knowledge, $P$. rusticus can be considered a microendemic and possibly endangered species due to its extremely restricted distribution and the continuous destruction of its habitat. Our results are important to clarify the systematics and the knowledge about the taxonomy and life history of the genus Pithecopus. Since the larvae of all species of Pithecopus are known, a comprehensive phylogenetic analysis would be welcome to help us understand the evolutionary relationships and systematics of larval characters in the genus.

\section{Acknowledgments}

J.P.B. thanks CAPES for the master's fellowship. T.G.S is grateful to $\mathrm{CNPq}$ for the research fellowships (process \#307352/2013-7 and \#308687/2016-17) and to Brena S. Gonçalves for preparing the photographs. Collecting permits (\#14468-9) were provide by the Instituto Chico Mendes de Conservação da Biodiversidade (ICMBio/SISBIO). Dr. A. Leyva (USA) provided English editing of the manuscript.

\section{Authors' Contributions}

Veluma Ialú Molinari De Bastiani: Substantial contribution in the concept and design of the study; Contribution to data collection; Contribution to data analysis and interpretation; Contribution to manuscript preparation; Contribution to critical revision, adding intelectual content.

Joana Priscilla Boschetti: Substantial contribution in the concept and design of the study; Contribution to data collection; Contribution to data analysis and interpretation; Contribution to manuscript preparation; Contribution to critical revision, adding intelectual content.

Tiago Gomes dos Santos: Substantial contribution in the concept and design of the study; Contribution to data collection; Contribution to data analysis and interpretation; Contribution to manuscript preparation; Contribution to critical revision, adding intelectual content. 
Elaine Maria Lucas: Substantial contribution in the concept and design of the study; Contribution to data collection; Contribution to data analysis and interpretation; Contribution to manuscript preparation; Contribution to critical revision, adding intelectual content.

\section{Conflicts of interest}

The authors declare that they have no conflict of interest related to the publication of this manuscript.

\section{References}

ALTIG, R. 2007. A primer for the morphology of anuran tadpoles. Herpetol. Conserv. Bio. 2(1):71-74.

BRANDÃO, R.A. 2002. A new species of Phyllomedusa Wagler, 1830 (Anura: Hylidae) from Central Brazil. J. Herpetol. 36(4):571-578.

BRANDÃO, R.A., ÁlvARES, G.F.R., CREMA, A. \& ZERBINI, G.J. 2009 Natural history of Phyllomedusa centralis Bokermann 1965 (Anura: Hylidae: Phyllomedusinae): tadpole and calls. S. Am. J. Herpetol. 4(1):61-68.

BRUSCHI, D.P., LUCAS, E.M., GARCIA, P.C.A. \& RECCO-PIMENTEL, S.M. 2014. Molecular and morphological evidence reveals a new species in the Phyllomedusa hypochondrialis group (Hylidae, Phyllomedusinae) from the Atlantic Forest of the highlands of Southern Brazil. PLoS ONE 9(8):e105608.

CARAMASCHI, U. 2006. Redefinição do grupo de Phyllomedusa hypochondrialis, com redescrição de P. megacephala (Miranda-Ribeiro, 1926), revalidação de $P$. azurea Cope, 1862 e descrição de uma nova espécie (Amphibia, Anura, Hylidae). Arq. Mus. Nacional 64:159-179.

CEI, J.M. 1980. Amphibians of Argentina. Monitore Zool. Ital. (N.S) Monogra. 2:1-609.

CRIVELlARI, L.B., LEIVAS, P.T., LEITE, J.C.M., GONÇALVES, D.S., MELLO, C.M., ROSSA-FERES, D.C.\& CONTE, C.E. 2014. Amphibians of grasslands in the state of Paraná, southern Brazil (Campos Sulinos). Herpetology Notes 7:639-654.

CRUZ, C.A.G. 1982. Conceituação de grupos de espécies de Phyllomedusinae brasileiras com base em caracteres larvários (Amphibia, Anura, Hylidae). Arq. Univ. Fed. Rur. Rio de Janeiro 5(2):149-171.

DUELLMAN, W.E. 1978. The biology of an equatorial herpetofauna in Amazonian Ecuador. Misc. Public. Mus. Nat. Hist. University of Kansas 65:1-352.

DUELLMAN W.E., MARION A.B. \& HEDGES S.B. 2016. Phylogenetics, classification, and biogeography of the tree frogs (Amphibia: Anura: Arboranae). Zootaxa 4104(1):1-109.

ETEROVICK, P.C. \& SAZIMA, I. 2004. Anfíbios da Serra do Cipó, Minas Gerais, Brasil. PUC Minas, Belo Horizonte.

FAIVOVICH, J., HADDAD, C.F.B., GARCIA, P.C.A., FROST, D., CAMPBELL, J., WHEELER, W.C. 2005. Systematic review of the frog family Hylidae, with special reference Hylinae: Phylogenetic analysis and taxonomic revision. Bull Am Mus Nat Hist. 294:1-240.

FAIVOVICH, J., HADDAD, C.F.B., BAÊTA, D., JUNGFER, K-H, ÁLVARES, G.F.R., BRANDÃO, R.A., SHEIL, C., BARRIENTOS, L.S., BARRIO AMORÓS, C.L., CRUZ, C.A.G. \& WHEELER, W.C. 2010. The phylogenetic relationships of the charismatic poster frogs, Phyllomedusinae (Anura, Hylidae). Cladistics 26:227-261.
FROST, D.R. 2018. Amphibian species of the world: an online reference. Version 6.0. American Museum of Natural History, New York, USA. Electronic Database. Available from: http://research.amnh.org/herpetology/amphibia/ index.html (last access on 10 July 2018)

GIARETTA, A.A., OLIVEIRA-FILHO, J.C. \& KOKUBUM, M.N.C. 2007. A new Phyllomedusa Wagler (Anura, Hylidae) with reticulated pattern on flanks from Southeastern Brazil. Zootaxa 1614:31-41.

GOSNER, K.L. 1960. A simplified table for staging anuran embryos and larvae with notes on identification. Herpetologica 16:183-190.

GROSJEAN, S. 2005. The choice of external morphological characters and developmental stages for tadpole-based anuran taxonomy: a case study in Rana (Sylvirana) nigrovittata (Blyth, 1855) (Amphibia, Anura, Ranidae). Contributions to Zoology 74:61-76.

HADDAD, C.F.B. \& PRADO, C.P.A. 2005. Reproductive modes in frogs and their unexpected diversity in the Atlantic Forest of Brazil. Bioscience 55:207-217.

KLEIN, R.M. 1978. Mapa Fitogeográfico do Estado de Santa Catarina. In Flora Ilustrada Catarinense (P.R. Reitz, ed.), V Parte - Mapa Fitogeográfico. Herbário Barbosa Rodrigues, Itajaí, p.25-26.

LANNOO, M.J. 1999. Integration: nervous and sensory systems. In Tadpoles: The Biology of Anuran Larvae (R.W. McDiarmid \& R. Altig, eds). The University of Chicago Press, Chicago, p.149-169.

LAVILLA, E.O. \& SCROCCHI, G.J. 1986. Morfometría larval de los géneros de Telmatobiinae (Anura: Leptodactylidae) de Argentina y Chile. Physis 44:39-43.

LUTZ, B. 1966. Pithecopus ayeaye, a new Brazilian hylid with vertical pupils and grasping feet. Copeia 1966(2):236-240.

MARTÍNEZ, D.R. 1990. Contribución al conocimiento de las larvas de anfibios de Venezuela. Mem. Socied. Cien. Nat. La Salle 50(131-134):391-403.

MCDIARMID, R.W. \& ALTIG, R. 1999. Tadpoles: The Biology of Anuran Larvae. The University of Chicago Press, Chicago.

OVERBECK, G.E., MÜller, S.C., FIDELIS, A., PFADENHAUER, J., PILLAR, V.P., BLANCO, C.C., BOLDRINI, I.I., BOTH, R. \& FORNECK, E.D. 2009. Os Campos Sulinos: um bioma negligenciado. In Campos Sulinos, conservação e uso sustentável da biodiversidade (V.P. Pillar, S.C. Müller, Z.M.S Castilhos, A.V. Jacques, eds). Ministério do Meio Ambiente, Brasília, p.24-41.

PEZZUTI, T.L., LEITE, F.S.F. \& NOMURA, F. 2009. The tadpole of Phyllomedusa itacolomi (Anura, Hylidae), with a description of the internal oral morphology. S. Am. J. Herpetol. 4(2):117-124.

PILLAR, V.P. \& VÉLEZ, E. 2010. Extinção dos Campos Sulinos em Unidades de Conservação: um fenômeno natural ou um problema ético? Nat. Conservação 8(1):84-86.

PYBURN, W.F. \& GLIDEWELL, J.R. 1971. Nests and behavior of Phyllomedusa hypochondrialis in Colombia. J. Herpetol. 5:49-52.

SCHULZE, A., JANSEN, M. \& KÖHLER, G. 2015. Tadpole diversity of Bolivia's lowland anuran communities: molecular identification, morphological characterisation, and ecological assignment. Zootaxa 4016(1):1-111.

SEGALLA, M.V., CARAMASCHI, U., CRUZ, C.A.G., GRANT, T., HADDAD, C.F.B., GARCIA, P.C.A., BERNECK, B.V.M. \& LANGONE, J.A. 2016. Brazilian Amphibians: list of species. Herpetologia Brasileira 5(2):34-46. 